\author{
N.A. Nikolov ${ }^{1 *}$, S.S. Makeyev ${ }^{2}$, O.Yu. Yaroshenko ${ }^{1}$, T.G. Novikova², M.V. Globa ${ }^{2}$ \\ ${ }^{1}$ Igor Sikorsky Kyiv Polytechnic Institute, Kyiv, Ukraine \\ ${ }^{2}$ The State Institution "Romodanov Neurosurgery Institute" of NAMSU, Kyiv, Ukraine

\section{QUANTITATIVE EVALUATION OF THE ABSOLUTE VALUE OF THE CEREBRAL BLOOD FLOW ACCORDING TO THE SCINTIGRAPHIC STUDIES WITH ${ }^{99 \mathrm{~m}}{ }^{\text {Tc-HMPAO** }}{ }^{* *}$}

Background. Represented by physical and mathematical model of cerebral hemodynamics, considered as a flow system. Objective. Development of cerebral blood flow quantification procedure according to scintigraphy data with ${ }^{99 \mathrm{~m} T c-}$ HMPAO.

Methods. Analytical, numerical and experimental study of the kinetics 99mTc-HMPAO in brain.

Results. For the purpose of quantitative assessment of volumetric cerebral blood flow according to the data of scintigraphy with ${ }^{99 \mathrm{~m}} \mathrm{Tc}-\mathrm{HMPAO}$, it was suggested to view the brain as a flow system. This allows calculating volumetric cerebral blood flow after numerical determination of the model parameters according to the results of indirect angiography and establishment of effective blood dilution volume in brain using single-photon emission-computed tomography. In this case, the suggested blood flow calculation procedure does not require any a priori knowledge of hemodynamics in a certain reference area.

Conclusions. Preliminary clinical studies allow characterizing the suggested approach to calculation of volumetric cerebral blood flow absolute values as appropriate.

Keywords: brain; perfusion; cerebral blood flow; mathematical modeling; ${ }^{99 \mathrm{~m} T c-H M P A O ; ~ S P E C T . ~}$

\section{Introduction}

Insufficiency of cerebral blood flow and hemodynamic supply of brain functional structures [1] is the factor underlying many pathological processes in brain. The methods used for evaluation of effective cerebral blood flow and perfusion include scintigraphic studies, in particular, indirect angiography and single-photon emission computed tomography (SPECT) [2]. Radiopharmaceuticals (RP) tropic to fatty tissue, i.e. lipophilic RPs, are frequently used for this purpose. There are several radiopharmaceuticals intended for brain perfusion studies, in particular, drugs labeled with 123 -iodine ( ${ }^{123}$ I-IMP) and $99 \mathrm{~m}$ technetium ( ${ }^{99 \mathrm{~m}} \mathrm{Tc}-\mathrm{HMPAO}$ and $\left.{ }^{99 \mathrm{~m}} \mathrm{Tc}-\mathrm{ECD}\right) .{ }^{99 \mathrm{~m}} \mathrm{Tc}-$ labeled hexamethylpropyleneamine oxime $\left({ }^{99 \mathrm{~m}} \mathrm{Tc}\right.$ HMPAO) is the most widely used one. Upon intravenous administration, ${ }^{99 \mathrm{~m}} \mathrm{Tc}-\mathrm{HMPAO}$ maximum penetration into brain tissue occurs during the first 2 minutes, after which it is maintained at permanent level for a long time (with maximum washout up to $1-2 \%$ ), which allows visualizing the changes in brain perfusion clearly.

Multi-compartment (or, to be more precise, three-compartment) models are used in modeling of ${ }^{99 \mathrm{~m}} \mathrm{Tc}-\mathrm{HMPAO}$ kinetics in brain [3]. The presented scheme is described by the system of linear differential equations

$$
\left\{\begin{array}{l}
\frac{d X}{d t}=k_{1} Z-k_{2} X-k_{3} X, \\
\frac{d Y}{d t}=k_{3} X-k_{4} Y .
\end{array}\right.
$$

Here, the coefficients $k_{1}, k_{2}, k_{3}$ are independent. The coefficient $k_{4}$ characterizing the transition of hydrophilic condition ${ }^{99 \mathrm{~m}} \mathrm{Tc}-\mathrm{HMPAO}$ back into lipophilic one, has the value one order of magnitude less than other coefficients, which allows neglecting it. Analysis of the system (1), as well as several empirical regulations, allowed N.A. Lassen and other authors to draw a relatively simple ratio for calculation of cerebral blood flow according to SPECT data $[4,5]$ :

$$
F_{i}=\left[\frac{\left(C_{i} / C_{r}\right) \alpha}{1+\alpha-\left(C_{i} / C_{r}\right)}\right] F_{r}
$$

where $C_{i}$ is the rate of radioactive count in the area of interest, where the rate of volumetric cerebral blood flow (VCBF) $F_{i}$ is calculated, $C_{r}$ is the rate of radioactive count in the reference area, where VCBF is known in advance and equals to $F_{r}, \alpha$ is empirical coefficient. In majority of cases, $\alpha$ is taken equal to 1.5; nevertheless, several authors mention that $\alpha$ can vary from 1 to 3.5 depending on the age and other clinical conditions, e.g. elevated blood pressure.

\footnotetext{
* corresponding author: nikolka_@ukr.net

${ }^{* *}$ The authors gratefully acknowledge the support of the project AMMODIT funded within EU H2020-MSCA-RICE
} 
Cerebellum area is selected as the reference area, where $\mathrm{VCBF}$ is taken equal to $55 \mathrm{ml} / \mathrm{min}$ per $100 \mathrm{~g}$ of brain [6].

In normal condition, based on literature data and the authors' own observations, assessment of effective perfusion of brain portions versus cerebellum is quite correct. Nevertheless, in the presence of brain pathological changes, quantitative parameters of brain hemodynamics obtained based on evaluation of SPECT images, often do not characterize deviations from the normal condition. Cerebellum perfusion and central hemodynamics may alter significantly based on the pathological process.

In relation with this, several studies paying attention at this fact attempt to improve VCBF calculation procedure using scintigraphy data, e.g. [7, 8], or other quantitative characteristics describing the blood flow indirectly, are used $[9,10]$. Nevertheless, no procedures allowing obtaining absolute values of $\mathrm{VCBF}$ in brain are described in literature.

\section{Problem statement}

Thus, the goal of this study is development of cerebral blood flow quantification procedure according to scintigraphy data with ${ }^{99 \mathrm{~m}} \mathrm{Tc}-\mathrm{HMPAO}$.

\section{Physical model}

In general terms, blood circulation in brain can be represented as a flow system where fluid inflow and outflow equality principle is met (Fig. 1). In accordance with suggested model, fluid with volume velocity $v$ and a drug with concentration $C$ dissolved in it is supplied to a vessel of volume $V$ with ideal momentary mixing. A part of the drug is specifically captured by perceptive superficial elements, and another part $\left(C^{\circ}\right)$ is eliminated from the system.

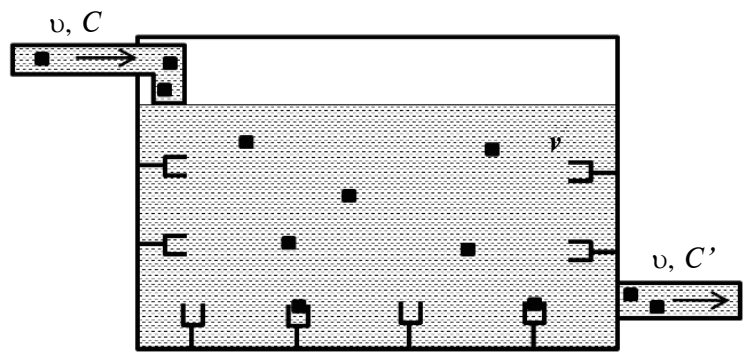

Fig. 1. Brain model as a flow system

Brain volume $V$ is ten times less than the body volume as a whole. This allows assuming that the drug concentration $C$ is actually independent of RP quantity absorbed in the brain. Thus, in case of ${ }^{99 \mathrm{~m}} \mathrm{Tc}-\mathrm{HMPAO}$, percentage of its inclusion into the brain versus the administered activity varies within the limits of $1.5-6 \%$, about $2.2 \%$ on average.

The physical model presented can be described by a system of first-order differential equations:

$$
\left\{\begin{array}{l}
\dot{x} \equiv \frac{d x}{d t}=v z-\frac{v}{V} x-k_{3} x, \\
\dot{y} \equiv \frac{d y}{d t}=k_{3} x,
\end{array}\right.
$$

where $x$ - quantity of free (unbound) ${ }^{99 \mathrm{~m}} \mathrm{Tc}$-HMPAO fraction in the brain, $y$ - quantity of ${ }^{99 \mathrm{~m}} \mathrm{Tc}-\mathrm{HMPAO}$ absorbed by brain structures, i.e. captured by fatty elements, $z$ - quantity of ${ }^{99 m}$ Tc-HMPAO contained in $1 \mathrm{ml}$ of blood supplied to the brain.

The physical and mathematical model (3) presented is identical to a multi-compartment model (1). The difference consists in the fact that the coefficients $k_{1}$ and $k_{2}$ in (1) are interrelated in accordance with (3.1). Volume velocity of cerebral blood flow $v$, in its turn, can be calculated when $v / \mathrm{V}$ ratio and dilution volume value $\mathrm{V}$ are established.

\section{Analytical solution of flow system model}

In brain scintigraphic studies with ${ }^{99 \mathrm{~m}} \mathrm{Tc}$ HMPAO, model (3) describes the RP kinetics immediately after intravenous administration of the drug within the first $30-120 \mathrm{~s}$. RP blood clearance since the drug supply into the brain is characterized by polyexponential behavior. Preliminary studies conducted have shown that, within $120 \mathrm{~s}$, RP blood clearance assessed via pericardial curve can be described by two exponents (Fig. 2) with error not exceeding $5-10 \%$ since the moment of the drug supply into the brain. The first exponent with time constant $\tau=1 / k_{11}$ is valid during the first $10-30 \mathrm{~s}$, and it should be interpreted as the drug dilution in circulating blood flow; the second one $\left(\tau=1 / k_{12}\right)$ gives essential yield after $20 \mathrm{~s}$ and characterizes the decrease of blood radioactivity due to the drug capture by body tissues.

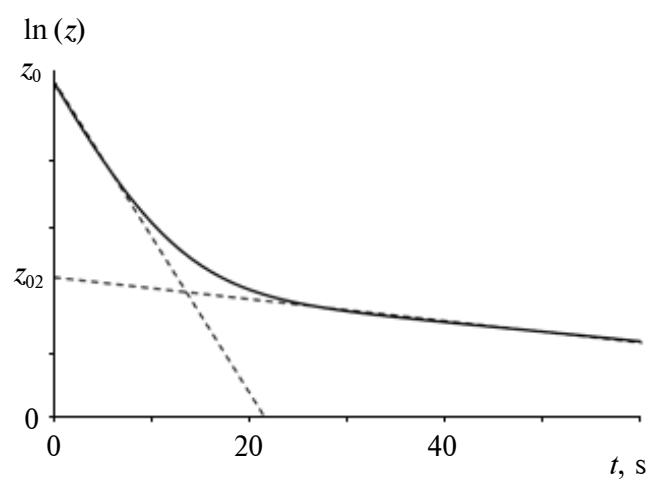

Fig. 2. Biexponential model of PR blood clearance 
Based on the assumption made, RP blood concentration will be described by

$$
z=z_{01} e^{-k_{11} t}+z_{02} e^{-k_{12} t}
$$

At the same time,

$$
\begin{gathered}
z_{0}=z_{01}+z_{02}, \\
z_{0}=\delta z_{02},
\end{gathered}
$$

where $\delta$ can be found from RP blood clearance according to pericardial curve.

Then

$$
z_{02}=z_{0} / \delta
$$

and

$$
z_{01}=z_{0}(1-1 / \delta)
$$

We should note that establishment of $z$ absolute values, according to planar scintigraphy data, is impossible due to the absence of information on the volume of the area of interest in pericardial region. $\delta, k_{11}$, and $k_{12}$ are the only measurable parameters.

After introduction of the designation

$$
W=\frac{u}{V},
$$

and with consideration of (4), (3.1) can be re-written as follows:

$$
\dot{x}=v\left(z_{01} e^{-k_{11} t}+z_{02} e^{-k_{12} t}\right)-W x-k_{3} x .
$$

Precise analytical solution of nonhomogeneous equation (6) is searched in the form:

$$
x=\bar{x}+\tilde{x},
$$

where $\bar{x}$ is general solution of homogeneous part of the equation (6):

$$
\dot{\bar{x}}=-W x-k_{3} x ;
$$

$\tilde{x}-$ particular solution of nonhomogeneous equation (6).

In more compact form, the equations can be presented as follows:

$$
\begin{gathered}
x=-\left(A_{1}+A_{2}\right) e^{-\left(W+k_{3}\right) t}+A_{1} e^{-k_{11} t}+A_{2} e^{-k_{12} t}, \\
y=k_{3}\left(\frac{\left(A_{1}+A_{2}\right)}{\left(W+k_{3}\right)}\left(e^{-\left(W+k_{3}\right) t}-1\right)\right. \\
\left.+\frac{1}{k_{11}} A_{1}\left(1-e^{-k_{11} t}\right)+\frac{1}{k_{12}} A_{2}\left(1-e^{-k_{12} t}\right)\right),
\end{gathered}
$$

where

$$
\begin{aligned}
A_{1}=\frac{D(1-1 / \delta)}{\left(-k_{11}+W+k_{3}\right)}, A_{2} & =\frac{D / \delta}{\left(-k_{12}+W+k_{3}\right)}, \\
\cup z_{0} & =D .
\end{aligned}
$$

\section{Identification of the model parameters}

During the brain scintigraphy, the dynamic study data allow obtaining radioactivity-time curves directly over the pericardial area immediately after RP administration into the body, which allows calculating coefficients $\delta, k_{11}, k_{12}$ over the head area as well, which is equivalent to the integral curve $(x+y)$ $=f(t)$.

At the same time, tissue background has to be taken into account in assessment of PR blood clearance velocity by pericardial curve, as ${ }^{99 \mathrm{~m}} \mathrm{Tc}-\mathrm{HMPAO}$ is also accumulated in heart tissues. ${ }^{99 \mathrm{~m}} \mathrm{Tc}-\mathrm{HMPAO}$ accumulation in pericardial area during the first minutes of the study was modeled by the following function:

$$
I_{p}=I_{p 0}\left(1-\exp \left(k_{p} t^{\prime}\right)\right),
$$

where $I_{p}-\mathrm{PR}$ accumulation in pericardial region, $I_{p 0}$ - maximum possible PR accumulation in pericardial area, $k_{p}$ - parameter, $t^{\prime}-$ time in which the reference point is interpreted as the moment of peak PR quantity in the area of interest of pericardial region. $I_{p 0}$ is selected at the level $95 \%$ of radioactivity count rate in pericardial region at $120 \mathrm{~s}$. An example of tissue background consideration result during assessment of RP blood clearance velocity is shown in Fig. 3.

Time curve of the drug kinetics in brain, i.e. $(x+y)=f(t)$ also allows assessing the parameter $D$, which, as follows from (7.4), characterizes maximum possible RP inflow into the brain. The lower limit of $D$ assessment is calculated as the maximum velocity of function $(x+y)=f(t)$ increase.

Thus, the unknown parameters for combined equation (11) are $W$ and $k_{3}$. Difference minimization function of experimentally obtained $(x+y)=f(t)$ and the total of (7.1) and (7.2) can be used for their identification.

Fig. 4, $a$ shows the approximation result of experimental data with the model (7), where $I$ - radioactivity count rate from "brain" region of interest, $I_{0}$ - radioactivity count rate from the administered activity, broken line - measurement data, solid line - modeling data. Modeling was performed using Matlab $12 \mathrm{~b}$ software system. Rather essential devia- 
tion of the model curve from the source data around the maximum point comes under notice when Fig. 4, $a$ is evaluated. This deviation is related with finite temporal resolving power of image recording ( 1 frame per $1 \mathrm{~s}$ ) and, as a consequence, under-estimation of $D$ parameter, assessed in initial approximation as the maximum derivative of the drug kinetics curve in brain during the first seconds of use. In order to minimize this effect, Monte Carlo method was used, in which $D$ parameter was varied within the limits of $20 \%$ of the initial minimum assessment according to uniform random distribution law. An exemplary result of the use of Monte Carlo method is shown in Fig. 4, $b$. As can be seen when Figs. 4, $a$ and $4, b$ are compared, initial data approximation error becomes less by $4-8 \%$ on average. Identification of parameters by using Monte Carlo method gives slightly better results approximating the measurement data. However, the disadvantage of the Monte Carlo method is not deterministic: decrease in the average approximation error can cause the overestimation of the $D$.
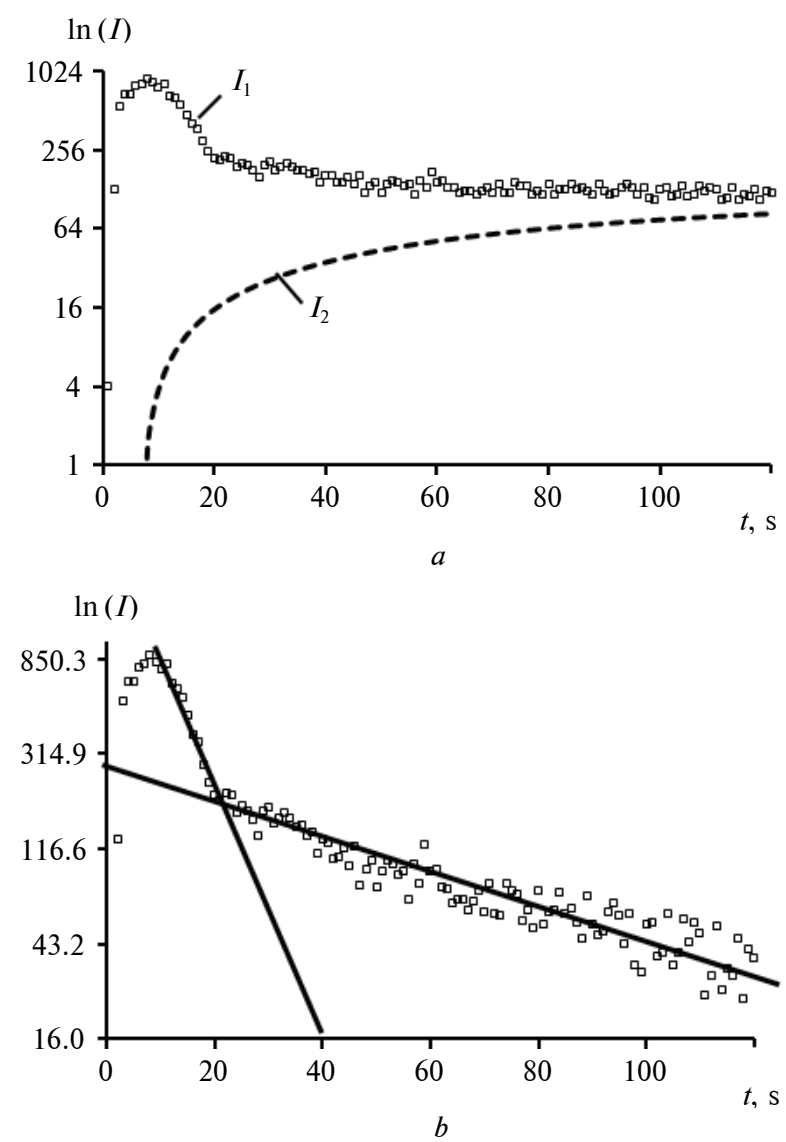

Fig. 3. Radioactive background consideration for pericardial curve: $a$ - radioactive count rate radioactivity count velocity over pericardial region $\left(I_{1}\right)$ and model approximation of RP accumulation by tissues $\left(I_{2}\right) ; b-$ difference curve $I_{1}-I_{2}$
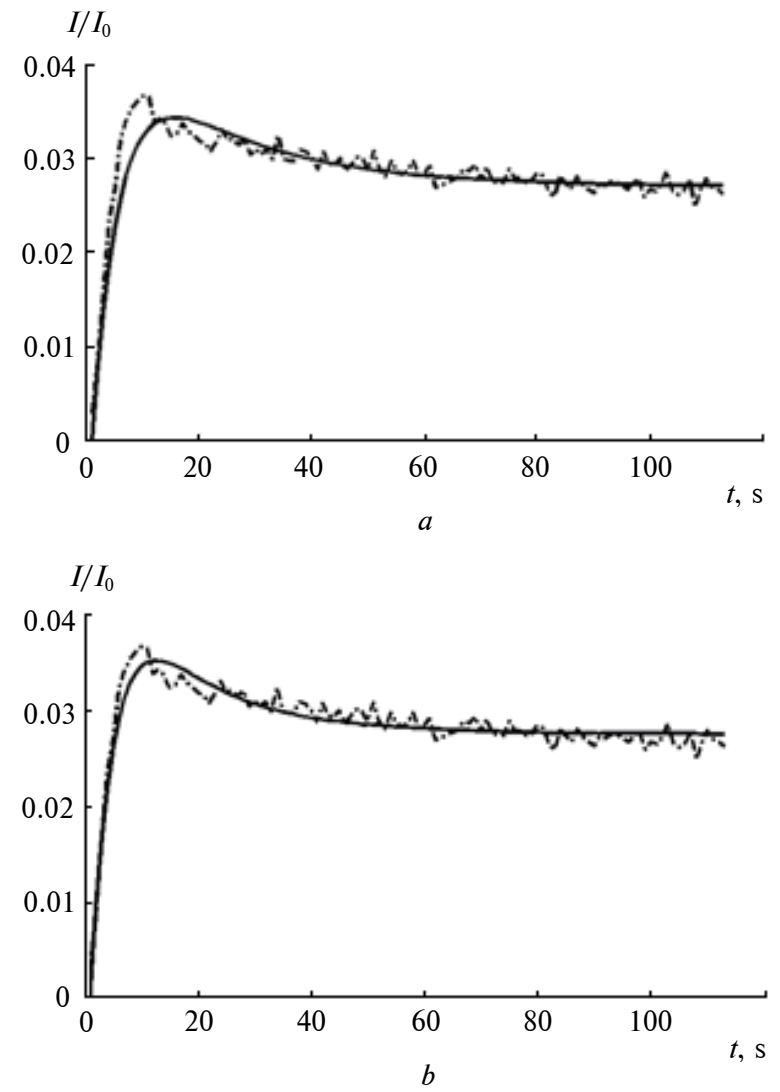

Fig. 4. Approximation of brain indirect angiography data without $(a)$ and with $(b)$ the use of Monte Carlo method

Based on (5), VCBF can be found if RP dilution volume in brain is known:

$$
\mathrm{v}=W \times V .
$$

The difficulty consists in the fact that $V$ is not equal to brain volume $\left(V_{0}\right)$; instead, it represents a certain effective value $\left(V<V_{0}\right)$. We should mention that $V_{0}$ is determined on the basis of SPECT images as the total of voxels contained in a closed surface describing the brain contour.

For assessment of $V$ value, a certain radioactive background cutoff level $(L)$ of SPECT images versus the maximum radioactivity was preset. The voxels where radioactivity count velocity exceeded the limit value $L$ comprised the volume $V$. $L$ was selected based on the assumption that cerebellar VCBF on average has to tend to $55 \mathrm{ml} / \mathrm{min} / 100 \mathrm{~g}$. Statistical analysis was performed in accordance with brain scintigraphic studies with ${ }^{99 \mathrm{~m}} \mathrm{Tc}-\mathrm{HMPAO}$ in 14 patients diagnosed with diabetic encephalopathy. Scintigraphic data collection protocol was as follows:

- radiometry of syringe with RP before administration to a patient (1 frame in $6 \mathrm{~s}$ );

- indirect angiography of brain and heart within $120 \mathrm{~s}$ (1 frame in $1 \mathrm{~s})$; 
- radiometry of syringe with RP residual radioactivity after administration ( 1 frame in $6 \mathrm{~s}$ );

- recording in 15-20 min after the drug administration in 64 SPECT projections of brain (1 frame in $20 \mathrm{~s}$ ).

Data collection matrix $-128 \times 128$ format. Activity of ${ }^{99 \mathrm{~m}} \mathrm{Tc}-\mathrm{HMPAO}$ was $(650 \pm 50) \mathrm{MBq}$. The drug administration was performed via bolus injection into the median cubital vein. The studies were conducted in bi-detector gamma-chamber E.Cam with low-energy high-resolution collimator. Indirect angiography was performed to the patients in the rest state, in the absence of visual stimuli.

The analysis showed that $L$ level is logarithmically dependent on the design parameter $W$ (Fig. 5) for the general patient population. In Fig. 5, $W_{M K}$ and $W$ are the parameters assessed with and without the use of Monte Carlo method, respectively, and $R$ is correlation coefficient between the regression line (solid line) and experimental data.
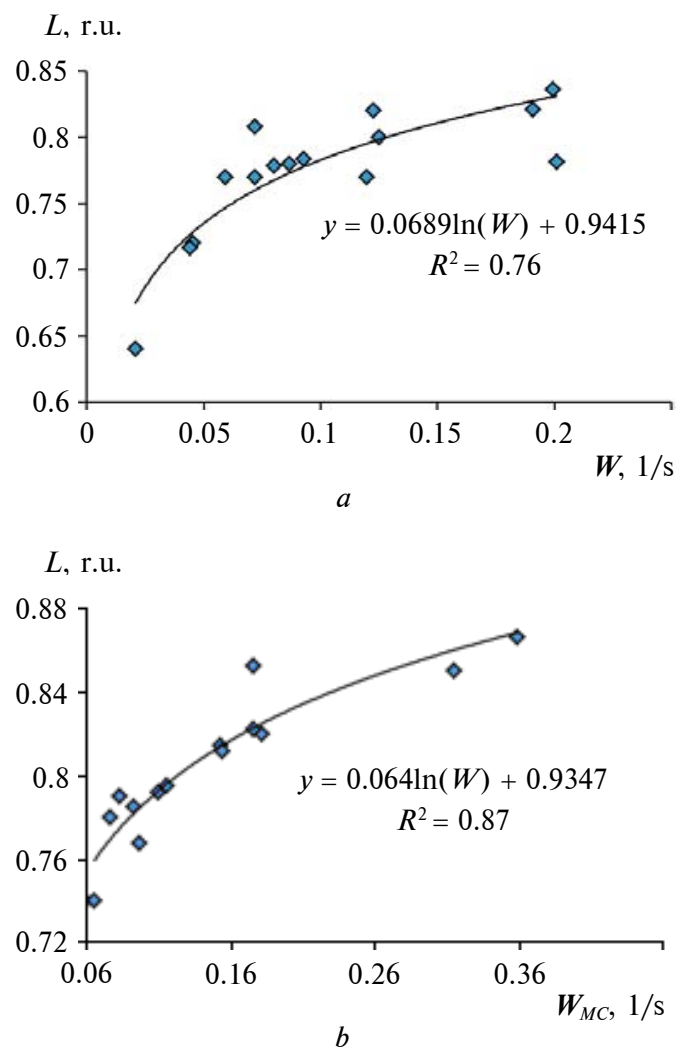

Fig. 5. Regression analysis of background cutoff level $(L)$ for establishment of RP effective dilution volume in brain without (a) and with (b) the use of Monte Carlo method

The obtained regressional relationships shown in Fig. 5 and (8) allow obtaining the brain VCBF in general in $\mathrm{ml} / \mathrm{min} / 100 \mathrm{~g}$ based on the assumption that the brain weight $(M)$ is equal to

$$
M=1,04 V_{0}(\mathrm{~g}),
$$

where $V_{0}$ is expressed as $\mathrm{cm}^{3}$.

$\mathrm{VCBF}$ of the area of interest $\left(V C B F_{A I}\right)$ on SPECT image was calculated using the formula:

$$
V C B F_{A 1}=\frac{\left\langle I_{A I}\right\rangle}{I_{\mathrm{Br}} / C} V C B F_{\mathrm{Br}},
$$

where $\left\langle I_{A I}\right\rangle$ - the mean radioactive count from the region of interest, $I_{\mathrm{Br}}$ - brain radioactive count upon $L$ background cutoff, $C$ - number of pixels corresponding to $V_{0}, V C B F_{\mathrm{Br}}-\mathrm{VCBF}$ of brain in total, calculated according to (8).

VCBF comparison results calculated using N.A. Lassen's method (with "Las" index) and according to the procedure presented without (" 0 " index) and with the use of Monte Carlo method ("MC" index) are shown in Table, where $\mathrm{CH}_{1}$ and $\mathrm{CHr}-$ $\mathrm{VCBF}$ in the left and right cerebellar hemispheres, $\mathrm{BH}_{1}$ and $\mathrm{BHr}-\mathrm{VCBF}$ in the left and right brain hemispheres, respectively. It should be mentioned that intraarterial drug administration was used in studies [4, 5] for VCBF calculation according to N.A. Lassen's method. This particularity might require the correction of the constants of RP transport in brain, Nevertheless, N.A. Lassen's procedure is based on VCBF calculation according to SPECT data, which is carried out in $15-20 \mathrm{~min}$ after the RP dosage, when the drug is uniformly distributed in blood stream, and its steady-state is achieved. Besides, as relatively high number of various fatty structures participates in RP capture, and administered ${ }^{99 \mathrm{~m}} \mathrm{Tc}$-HMPAO activities are low enough for involvement of the substrate absorption limitation principle (Monod model or Michaelis-Menten model), the constants of drug transport in brain should not essentially alter depending on its administration site to the body. In relation with this, VCBF calculation formula according to N.A. Lassen's method has become widely accepted in intravenous administration as well $[3,6,8]$.

The data shown in Table are indicative of the fact that VCBF values assessed using different methods have comparable values; $\mathrm{VCBF}_{\mathrm{MC}}$ values are slightly closer to $\mathrm{VCBF}_{\mathrm{Las}}$ values than $\mathrm{VCBF}_{0}$ values; the average correlation coefficient tends to 0.45 . You can select patients where hemispheric VCBF exceeds $\mathrm{VCBF}_{\mathrm{Las}}$ and vice versa. Thus in patients with elevated $\mathrm{VCBF}\left(\mathrm{VCBF}>\mathrm{VCBF}_{\mathrm{Las}}\right)$ there is an increased percentage of uptake RP with respect to the administration of the active (more than $4 \%$ ), in pa- 
Table. Comparison of VCBF values assessed using different calculation methods

\begin{tabular}{|c|c|c|c|c|c|c|c|c|c|c|c|c|}
\hline \multirow{2}{*}{$\begin{array}{l}\text { Pat. } \\
\text { No }\end{array}$} & \multicolumn{3}{|c|}{$\begin{array}{c}\mathrm{CH}_{\mathrm{l}}, \\
\mathrm{ml} / \mathrm{min} / 100 \mathrm{~g}\end{array}$} & \multicolumn{3}{|c|}{$\begin{array}{c}\mathrm{CH}_{\mathrm{r}}, \\
\mathrm{ml} / \mathrm{min} / 100 \mathrm{~g}\end{array}$} & \multicolumn{3}{|c|}{$\begin{array}{c}\mathrm{BH}_{1}, \\
\mathrm{ml} / \mathrm{min} / 100 \mathrm{~g}\end{array}$} & \multicolumn{3}{|c|}{$\begin{array}{c}\mathrm{BH}_{\mathrm{r}}, \\
\mathrm{ml} / \mathrm{min} / 100 \mathrm{~g}\end{array}$} \\
\hline & $\mathrm{VCBF}_{\mathrm{Las}}$ & $\mathrm{VCBF}_{0}$ & $\mathrm{VCBF}_{\mathrm{MC}}$ & $\mathrm{VCBF}_{\text {Las }}$ & $\mathrm{VCBF}_{0}$ & $\mathrm{VCBF}_{\mathrm{MC}}$ & $\mathrm{VCBF}_{\text {Las }}$ & $\mathrm{VCBF}_{0}$ & $\mathrm{VCBF}_{\mathrm{MC}}$ & $\mathrm{VCBF}_{\mathrm{Las}}$ & $\mathrm{VCBF}_{0}$ & $\mathrm{VCBF}_{\mathrm{MC}}$ \\
\hline 1 & 55.0 & 47.2 & 40.9 & 52.1 & 45.7 & 39.6 & 34.8 & 35.0 & 30.3 & 36.7 & 36.3 & 31.5 \\
\hline 2 & 55.0 & 62.0 & 48.5 & 55.0 & 62.0 & 48.5 & 42.0 & 52.3 & 40.9 & 41.2 & 51.6 & 40.4 \\
\hline 3 & 55.0 & 63.3 & 53.7 & 54.5 & 62.9 & 53.4 & 36.5 & 48.6 & 41.2 & 36.0 & 48.1 & 40.8 \\
\hline 4 & 55.0 & 92.6 & 43.7 & 54.9 & 92.5 & 43.7 & 38.5 & 73.7 & 34.8 & 38.1 & 73.1 & 34.5 \\
\hline 5 & 52.5 & 46.4 & 68.9 & 55.0 & 47.7 & 70.9 & 40.8 & 39.5 & 58.6 & 40.0 & 38.9 & 57.8 \\
\hline 6 & 52.6 & 70.6 & 65.9 & 55.0 & 72.5 & 67.7 & 33.5 & 52.4 & 48.9 & 33.4 & 52.2 & 48.8 \\
\hline 7 & 55.0 & 35.3 & 25.5 & 52.1 & 34.2 & 24.1 & 32.3 & 24.8 & 17.5 & 32.7 & 25.0 & 17.7 \\
\hline 8 & 55.0 & 63.4 & 58.5 & 51.9 & 61.3 & 56.5 & 40.2 & 52.0 & 47.9 & 34.8 & 47.1 & 43.4 \\
\hline 9 & 54.1 & 59.5 & 53.3 & 55.0 & 60.2 & 53.8 & 35.2 & 45.0 & 40.3 & 39.0 & 48.3 & 43.2 \\
\hline 10 & 54.9 & 103.3 & 101.5 & 55.0 & 103.5 & 101.6 & 38.3 & 82.1 & 80.6 & 37.9 & 81.4 & 79.9 \\
\hline 11 & 55.0 & 59.8 & 52.5 & 54.2 & 59.3 & 52.1 & 35.6 & 45.1 & 39.6 & 34.3 & 43.9 & 38.6 \\
\hline 12 & 52.3 & 47.1 & 38.2 & 55.0 & 48.6 & 39.4 & 33.7 & 35.2 & 28.5 & 33.3 & 34.9 & 28.3 \\
\hline 13 & 53.6 & 63.5 & 54.1 & 55.0 & 64.6 & 55.0 & 37.8 & 50.7 & 43.2 & 41.4 & 53.9 & 45.9 \\
\hline 14 & 53.2 & 47.5 & 48.9 & 55.0 & 48.4 & 49.9 & 37.5 & 37.9 & 39.0 & 37.2 & 37.6 & 38.8 \\
\hline$M V$ & 54.1 & 61.5 & 53.9 & 54.3 & 61.7 & 54.0 & 36.9 & 48.2 & 42.2 & 36.8 & 48.0 & 42.1 \\
\hline$\sigma$ & \pm 1.1 & \pm 17.6 & \pm 17.0 & \pm 1.2 & \pm 17.7 & \pm 17.4 & \pm 2.8 & \pm 14.5 & \pm 14.2 & \pm 2.8 & \pm 14.3 & \pm 13.9 \\
\hline
\end{tabular}

Note. $M V-$ Mean value; $\sigma-$ standard deviation.

tients with a reduced percentage of $\mathrm{VCBF}(\mathrm{VCBF}$ $<\mathrm{VCBF}_{\text {Las }}$ ) enable the RP was less than $2 \%$. According to our data enable normal percentage of uptake ${ }^{99 m}$ Tc-HMPAO is in the average range $4-5 \%$. Fig. 6 is an example of a low percentage of uptake of RP (less than $1.7 \%$ ) and lower total VCBF than $\mathrm{VCBF}_{\text {Las }}$. It should be noted a significant change in the spatial distribution of the ${ }^{99 \mathrm{~m}} \mathrm{Tc}-\mathrm{HMPAO}$ in relation to the norm provided in [6].

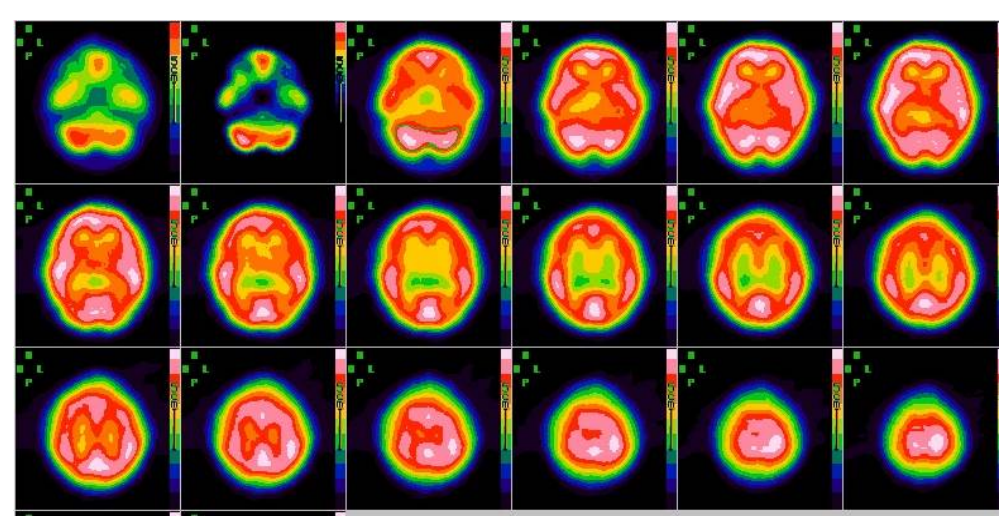

Fig. 6. Brain concussion. Hypoperfusion signs in the left frontal area. Asymmetry in cerebellar hemispheres $S<D$ (diaschisis), percentage of uptake $-2.7 \%$

At this stage of the research, to clinical data obtained should be treated as preliminary. For a wider clinical testing of the proposed methodology and its implementation into clinical practice it is necessary to solve the problems:

- development software for registration of multimodal images (SPECT/CT or SPECT/MRI);

- development of a protocol for data analysis and description of the results;

- automated image analysis process;

- carry out detailed, extensive clinical research.

\section{Conclusions}

For the purpose of quantitative assessment of volumetric cerebral blood flow according to the data of scintigraphy with ${ }^{99 \mathrm{~m}} \mathrm{Tc}-\mathrm{HMPAO}$, it was suggested to view the brain as a flow system. This allows calculating volumetric cerebral blood flow after numerical determination of the model parameters according to the results of indirect angiography and establishment of effective blood dilution volume in brain using single-photon emission-computed tomography. In this case, the suggested blood flow calculation procedure does not require any a priori knowledge of hemodynamics in a certain reference area.

Calculation of volumetric cerebral blood flow provides for the consistency of ratio $(W)$ between the blood flow rate and the effective drug dilution 
volume in brain. The effective drug dilution volume in brain can be established using single-photon emission-computed tomography with preset radioactive background cutoff level. Regression analysis of experimental data allows describing the relationship between radioactive background cutoff level and $W$ value according to logarithmic law with correlation coefficient more than 0.9 .

Preliminary clinical studies allow characterizing the suggested approach to calculation of volumetric cerebral blood flow absolute values as appropriate.

\section{References}

[1] Diagnostics and Treatment of Chronic Forms of Cerebral Circulatory Insufficiency in Patients with Essential Hypertension, V.F. Mordovin and R.S. Karpov, eds. Tomsk, Russia: SST, 2011 (in Russian).

[2] L.A. Bockeria et al., "Diagnostic methods of cerebral hemodynamics and the level of cerebral perfusion in patients with occluding lesions of brachiocephalic arteries", The Bulletin of A.N. Bakoulev Scientific Center for Cardiovascular Surgery of Russian Academy of Medical Sciences. Cardiovascular Diseases, vol. 13, no. 1, pp. 5-17, 2012 (in Russian).

[3] K. Borch and G. Greisen, "99mTc-HMPAO as a tracer of cerebral blood flow in newborn infants", J. Cereb. Blood Flow Metab., 1997, no. 17, pp. 448-454. doi: 10.1097/00004647-199704000-00010

[4] N.A. Lassen et al., "The retention of [99mTc]-d,I-HM-PAO in the human brain after intracarotid bolus injection: A kinetic analysis", J. Cereb. Blood Flow Metab., no. 8, pp. S13-S22, 1988. doi: 10.1038/jcbfm.1988.28

[5] A.R. Andersen et al., "Quantitative measurements of cerebral blood flow using SPECT and [99mTc]-d,I-HM-PAO compared to Xenon-I33”, J. Cereb. Blood Flow Metab., no. 8, pp. S69-S81, 1988. doi: 10.1038/jcbfm.1988.35

[6] H. Fro et al., "Database of normal human cerebral blood flow measured by SPECT: I. Comparison between I-123-IMP, Tc-99m-HMPAO, and Tc-99m-ECD as referred with O-15 labeled water PET and voxel-based morphometry", Annals Nucl. Med., vol. 20, no. 2, pp. 131-138, 2006. doi: 10.1007/BF02985625

[7] M. Kameyama, "Lassen's equation is a good approximation of permeability-surface model: new a values for 99mTc-HMPAO and 99mTc-ECD”, J. Cereb. Blood Flow Metab., vol. 34, pp. 1157-1161, 2014. doi: 10.1038/jcbfm.2014.64

[8] K. Murase et al., "Kinetic behavior of Technetium-99m-HMPAO in the human brain and quantification of cerebral blood flow using dynamic SPECT”, J. Nucl. Med., vol. 33, no. 1, pp. 135-143, 1992.

[9] I.A. Illán et al., "Bilateral symmetry aspects in computer-aided Alzheimer's disease diagnosis by single-photon emissioncomputed tomography imaging”, Artif. Intell. Med., no. 56, pp. 191-198, 2012. doi: 10.1016/j.artmed.2012.09.005

[10] N.A. Nikolov et al., "Integral estimate of spatial distribution of 99mTc-HMPAO in brain of patients with mild cognitive changes”, Radioelectron. Commun. Syst., vol. 57, no. 12 (630), pp. 52-61, 2014. doi: 10.3103/S073527271412005X

М.О. Ніколов, С.С. Макеєв, О.Ю. Ярошенко, Т.Г. Новікова, М.В. Глоба

КІЛЬКІСНА ОЦІНКА АБСОЛЮТНОГО МОЗКОВОГО КРОВОТОКУ ЗА ДАНИМИ СЦИНТИГРАФІЧНИХ ДОСЛІДЖЕНЬ 3 ${ }^{99 \mathrm{M}} \mathrm{ТС-ГМПАО}$

Проблематика. Розглядається фрізико-математична модель гемодинаміки головної мозку як проточна система.

Мета дослідження. Розробка методології кількісної оцінки мозкового кровотоку за даними сцинтиграфії з ${ }^{99 \mathrm{~m}} \mathrm{Tc-ГMПАО.}$

Методика реалізації. Аналітичне, числове і експериментальне дослідження кінетики ${ }^{99 m}$ Тс-ГМПАО в головному мозку.

Результати досліджень. Для кількісної оцінки об'ємного мозкового кровотоку за даними сцинтиграфії ${ }^{99 m}$ Тс-ГМПАО було запропоновано розглядати мозок як проточну систему. Це дає змогу розрахувати об'ємний мозковий кровоток на основі числового визначення параметрів моделі за результатами непрямої ангіографії та оцінки ефективного об'єму розведення крові в мозку за даними однофотонної емісійної комп'ютерної томографії. Запропонована методика розрахунку кровотоку не вимагає апріорного знання гемодинаміки в певній еталонній ділянці мозку.

Висновки. Попередні клінічні дослідження дають змогу стверджувати про коректність розрахунку абсолютного мозкового кровотоку на основі запропонованого методу за даними сцинтиграфії з ліпофільними радіофармпрепаратами.

Ключові слова: головний мозок; перфузія; мозковий кровоток; математичне моделювання; ${ }^{99 \mathrm{~m}} \mathrm{Tc-ГМПАО,} \mathrm{однофотонна}$ емісійна комп'ютерна томографія.

Н.А. Николов, С.С. Макеев, О.Ю. Ярошенко, Т.Г. Новикова, М.В. Глоба

КОЛИЧЕСТВЕННАЯ ОЦЕНКА АБСОЛЮТНОГО МОЗГОВОГО КРОВОТОКА ПО ДАННЫМ СЦИНТИГРАФИЧЕСКИХ ИССЛЕДОВАНИЙ С ${ }^{99 \mathrm{M}}$ ТС-НМРАО

Проблематика. Рассматривается физико-математическая модель гемодинамики головного мозга как проточная система. Цель исследования. Разработка методологии количественной оценки мозгового кровотока по данным сцинтиграфии с ${ }^{99 \mathrm{~m}}$ Tc-HMPAO. 
Методика реализации. Аналитическое, численное и экспериментальное исследование кинетики ${ }^{99 \mathrm{~m}} \mathrm{Tc-ГМПАО} \mathrm{в} \mathrm{голов-}$ ном мозге.

Результаты исследований. Для количественной оценки объемного мозгового кровотока по данным сцинтиграфии с ${ }^{99 m}$ Tс-НMPAО было предложено рассматривать мозг как проточную систему. Это позволяет рассчитать объемный мозговой кровоток на основе численного определения параметров модели по результатам непрямой ангиографрии и оценки эффрективного объема разбавления крови в мозге по данным однофотонной эмиссионной компьютерной томографии. Предлагаемая методика расчета кровотока не требует априорного знания гемодинамики в определенной эталонной области мозга.

Выводы. Предварительные клинические исследования позволяют утверждать о корректности расчета абсолютного мозгового кровотока на основе предложенного метода по данным сцинтиграфии с липофильными радиофармпрепаратами.

Ключевые слова: головной мозг; перфузия; мозговой кровоток; математическое моделирование; ${ }^{99 \mathrm{~m}} \mathrm{Tc-ГМПАО,} \mathrm{однофо-}$ тонная эмиссионная компьютерная томография.

Рекомендована Радою

Надійшла до редакції

факультету прикладної математики

10 січня 2017 року

КПІ ім. Ігоря Сікорського 